\title{
Evaluation of analgesic and sedative effects of repeated and increasing doses of xylazine $\mathrm{HCI}$ in sheep*)
}

\author{
MUSA GENCCELEP, ABDULLAH KARASU
}

\author{
Department of Surgery, Faculty of Veterinary Medicine, University of Yuzuncu Yil, 65080, Van, Turkey
}

\section{Genccelep M., Karasu A.}

\section{Evaluation of analgesic and sedative effects of repeated and increasing doses of xylazine HCI in sheep}

\section{Summary}

The aim of the study was to investigate the sedative and analgesic biochemical and clinical effects of repeated and increasing doses of xylazine $\mathrm{HCl}$ in sheep.

Five clinically healthy Akkaraman rams were used. Xylazine was administered intramuscularly at an initial dose of $0.4 \mathrm{mg} / \mathrm{kg}$ to induce sedation. The second, third and fourth doses were $20 \%$ larger than the previous dose, that is, $0.48,0.57$ and $0.68 \mathrm{mg} / \mathrm{kg}$ doses, respectively. They were administered intramuscularly four times at 4-day intervals. The rectal temperature, heart rate and respiratory rate, as well as the rumen motility of all animals, were evaluated before and after xylazine administration. The depths of sedation and analgesia and the control of reflexes, along with various biochemical parameters, were studied. Although the respiration rate increased until the $15^{\text {th }} \mathrm{min}$, it approached the control value at the $30^{\text {th }} \mathrm{min}$ and decreased after the $45^{\text {th }}$ min. Ruminal contractions progressively decreased from the $5^{\text {th }}$ min to the $60^{\text {th }} \mathrm{min}$. All levels of sedation were observed in all sheep. The degree of analgesic effect was 0 during mild and moderate sedation periods, and 1-2 during deep sedation. Of all biochemical parameters assessed, only the glucose concentration increased. It was therefore concluded that in order to obtain the same sedation level in sheep in the 4 days following an administration of xylazine, the previous dose should be increased by $20 \%$.

Keywords: sheep, xylazine $\mathrm{HCl}$, repeated sedation

General anaesthesia is not widely used in livestock, as its administration results in different additive effects, such as ruminal tympanism, regurgitation of reticuloruminal ingredients and aspiration of esophageal reflux or salivary material (23). Therefore, sedatives and tranquilising drugs play an important role in dayto-day veterinary practice (21), and a wide range of such agents are used as painkillers and myorelaxants in animals undergoing surgical procedures. They are necessary in veterinary medicine, as they assist in preventing the animal from struggling during inspection and in sustaining anaesthesia, thus limiting the quantity of anaesthetic used (18). The use of these agents facilitates intravenous catheterisation, examination of the rectum, uterus and vagina, and the performance of surgical procedures (e.g., amputation of the tail, dehorning and abscess opening) under local anaesthesia $(9,21)$.

\footnotetext{
*) This study was supported by the Scientific Research Project Directory of the University of Yüzüncü Y1l (Project No. 2012-VF-B020). We would like to thank them for their support.
}

Xylazine hydrochloride, the first $\alpha-2$ adrenergic receptor agonist to be employed as a sedative in veterinary practice, remains the most frequently administered anaesthetic for ruminants $(3,10)$. Although clinical sedative dosages of xylazine $\mathrm{HCl}$ do not provoke hypoxaemia in dogs, its intravenous administration to sheep at sedative and non-sedative doses has resulted in severe hypoxaemia (3). Xylazine $\mathrm{HCl}$ generally generates a dose-dependent sedative-hypnotic state, and surgical anaesthesia can be achieved by its use in combination with other anaesthetics. The administration of xylazine $\mathrm{HCl}$ to ruminants is associated with moderate to deep cardiopulmonary depression and, at higher doses, with ruminal stasis, apnoea and bradycardia. The sedative is ineffective in excited animals, and further disadvantages include prolonged induction and recovery (10). It has cardiopulmonary effects, such as bradycardia, changes in arterial blood pressure, tachypnoea with pulmonary oedema and arterial hypoxaemia. However, despite these deep cardiopulmonary effects, sedation may not be as marked as expected, 
and a lying down posture may not be achieved when xylazine $\mathrm{HCl}$ is administered to sheep (2).

Our previous study showed that repeated sedation of sheep with xylazine $\mathrm{HCl}$ reduced the degree of sedation in the third and fourth administrations (11). In a literature search, we were unable to find any study in which the clinical, biochemical and sedative effects of repeated and increasing doses of xylazine $\mathrm{HCl}$ on sheep are examined. Therefore, the aim of the present study was to investigate the sedative and analgesic biochemical and clinical effects of repeated and increasing doses of xylazine $\mathrm{HCl}$ in sheep.

\section{Material and methods}

Animals. Five healthy male sheep (Akkaraman breed) aged 18-20 months and weighing 50-60 kg were used. The animals were kept in the Yüzüncü Y1l University Research and Application Farm, Van, Turkey, and received the same feeding regime throughout the study duration. The consent of the Ethics Council of the University of Yüzüncü Yıl was obtained prior to beginning the study.

Initiation of sedation. Feeding was suspended starting from $12 \mathrm{~h}$ prior to the study. To induce sedation, xylazine $\mathrm{HCl}$ (Rompun 2\%, Bayer) was administered intramuscularly four times at four-day intervals. The initial dose was 0.40 $\mathrm{mg} / \mathrm{kg}$. The second, third and fourth doses were each larger by $20 \%$ than the previous dose, that is, $0.48,0.57$ and 0.68 $\mathrm{mg} / \mathrm{kg}$ doses, respectively.

Clinical and reflexes evaluation. To evaluate clinical, reflexes, the degree of sedation, analgesic effect and biochemical parameters, we used the method from our previous study (11). Rectal temperature, pulse rate, respiration rate, pulmonary sounds, rumen activity and reflexes were evaluated at $0 \mathrm{~min}$ (before xylazine $\mathrm{HCl}$ administration - baseline) and then at 5, 15, 30, 45, 60, 75, 90, 105 and 120 min following xylazine $\mathrm{HCl}$ administration. Rectal temperature was measured with a digital thermometer. Reflexes (palpebral, corneal, pupillary, patellar and triceps brachii reflexes and eye movements) were controlled. Pulmonary sounds, rumen activities, pulse rate and respiration rate were auscultated

Tab. 1. Scoring of sedation

\begin{tabular}{|l|l|l|}
\hline \multicolumn{1}{|c|}{ Sedation level } & \multicolumn{1}{|c|}{ Behaviour } & \multicolumn{1}{c|}{ End of sedation } \\
\hline No Sedation & $\begin{array}{l}\text { standing, alert, normal behaviour } \\
\text { standing, alert, reduced head and ear } \\
\text { Movements, head drop, ataxia }\end{array}$ & redurned back to normal behaviour \\
Moderate Sedation & $\begin{array}{l}\text { sternal recumbency, head up or unable } \\
\text { to support head } \\
\text { lateral recumbency, uncoordinated head } \\
\text { and leg movements or no movements }\end{array}$ & $\begin{array}{l}\text { attained a standing posture } \\
\text { attained sterno-abdominal or standing } \\
\text { posture }\end{array}$ \\
\hline
\end{tabular}

Tab. 2. Scoring of analgesic effect

\begin{tabular}{|c|l|}
\hline Analgesic score & \\
\hline $\mathbf{0}$ & no analgesic effect (normal strong reaction to painful stimuli) \\
$1-2$ & no analgesic effect (normal strong reaction to painful stimuli) \\
\hline $3-4$ & $\begin{array}{l}\text { moderate analgesic effect (no response to needle-prick stimulation of the skin, } \\
\text { but there are responses to needle-prick stimulation of subcutaneous tissue) } \\
\text { deep analgesic effect (no response to insertion of the needle deep into } \\
\text { subcutaneous tissue - no leg movement, or contraction) }\end{array}$ \\
\hline $5-6$ &
\end{tabular}

with a stethoscope. In addition, it was determined whether oro-nasal discharge and urination began after the administration of xylazine $\mathrm{HCl}$.

Evaluation of sedation. Sedation scoring was carried out according to a modified scoring system of Kastner et al. (13) (Tab. 1).

Evaluation of the analgesic effect. Analgesia was evaluated before drug administration (baseline) and at 5-min intervals after drug administration until complete recovery. The onset and duration of analgesia were evaluated by applying painful stimuli with a 23-gauge needle, which was inserted through the skin and the underlying tissues in different parts of the body (perineal, left front and hind limbs, interdigital and corona regions). All procedures were performed at the same points. Analgesic effects were evaluated by a single investigator throughout the experiment, and the analgesic assessment (Tab. 2) was made according to a modified scoring system of Khan et al. (14).

Biochemical evaluation. In all administrations, blood samples were taken from the jugular vein of all animals prior to sedation, during sedation (at the $45^{\text {th }}$ min after xylazine $\mathrm{HCl}$ administration) and after sedation (at the $120^{\text {th }}$ min after xylazine $\mathrm{HCl}$ administration). The blood samples obtained were centrifuged at 5,000 rpm to separate the serum, which was then frozen at $-18^{\circ} \mathrm{C}$ and stored until the day of the analyses. The serum was then thawed, after which its glucose, total bilirubin, blood urea nitrogen (BUN), aspartate aminotransferase (AST), alanine transaminase (ALT), alkaline phosphatase (ALP), calcium $\left(\mathrm{Ca}^{2+}\right)$, sodium $\left(\mathrm{Na}^{+}\right)$, potassium $\left(\mathrm{K}^{+}\right)$and chloride $(\mathrm{Cl})$ values were measured with an analyser (Roche - Hitachi, Germany).

Statistical evaluation. Numerical values obtained during the applications were compared by the Statistical Package for the Social Sciences program for Windows, version 21.0, using Student's t-test. A value of $\mathrm{p}<0.05$ was considered statistically significant.

\section{Results and discussion}

Oro-nasal discharge and urination began 5 min after injection at the earliest in all administrations, and continued at various intervals until the $75^{\text {th }}$ min at the latest.

The animals urinated five times at most during the $120 \mathrm{~min}$ duration. Rectal temperature increased by a maximum of $0.4^{\circ} \mathrm{C}$ above the control values in the first 30 min after the injection in all administrations, and then decreased by a maximum of $0.6^{\circ} \mathrm{C}$. The pulse rate was lower than the control values at the $5^{\text {th }} \mathrm{min}$ in all administrations, and remained lower for $120 \mathrm{~min}$. The changes in rectal temperature and the pulse rate were not statistically significant $(p>0.05)$. Although the respiration rate increased until the $15^{\text {th }} \mathrm{min}$, it approached the control value at the $30^{\text {th }}$ min and decreased after the $45^{\text {th }}$ min. The changes in the respiration rate were statistically significant 
$(\mathrm{p}<0.05)$ (Tab. 3). Ruminal contractions decreased from the $5^{\text {th }} \mathrm{min}$, reaching the minimum level at the $30^{\text {th }} \mathrm{min}$. An increase in ruminal contractions was determined from the $45^{\text {th }}$ to the $120^{\text {th }} \mathrm{min}$, and the values at the $45^{\text {th }}$ and $60^{\text {th }}$ min were statistically significant $(\mathrm{p}<0.05)$ (Tab. 4).

Reflexes (palpebral, corneal, pupillary, patellar and triceps brachii reflexes and eye movements) were lost only during deep sedation periods.

At the first administration, one animal was mildly sedated, two animals were moderately sedated, and two were deeply sedated. In the subsequent administrations, mild sedation occurred in two animals, one animal was moderately sedated, and two were deeply sedated. At the first and third administrations, one animal entered the mild sedation stage after showing moderate sedation at the stage of awakening from deep sedation. Other animals entered mild sedation without entering the moderate sedation stage. The sedation findings are presented in Table 5.

In pain tests, the analgesic score was 0 (normal, strong reaction to painful stimuli) during periods of mild and moderate sedation, and 1-2 (depressed reaction to painful stimuli) during deep sedation. The duration of analgesia ranged from 10 to $40 \mathrm{~min}$.

The examination of the biochemical parameters showed that xylazine $\mathrm{HCl}$ caused hyperglycaemia $(p<0.01)$. However, changes in some of the other parameters (total bilirubin, BUN, AST, ALT, ALP, $\mathrm{Ca}^{2+}, \mathrm{Na}^{+}, \mathrm{K}^{+}$and $\mathrm{Cl}$ ) were statistically insignificant $(\mathrm{p}>0.01)$.

Xylazine $\mathrm{HCl}$ was the first $\alpha 2$-adrenergic agonist to be used in veterinary medicine, and its clinical use was first described in 1969 in a number of species (19). Ruminants are 10-20 times more sensitive to xylazine $\mathrm{HCl}$ than other species, and goats are more sensitive than sheep. In sheep, the half-life of xylazine $\mathrm{HCl}$ is short, and excretion from plasma is rapid when xylazine $\mathrm{HCl}$ is administered intravenously or intramuscularly (12). Xylazine $\mathrm{HCl}$ in ruminants may lead to excessive salivation due to decreased swallowing, and animals tend to drool saliva. It also results in polyuria due to hyperglycaemia $(5,8)$. Previous studies have shown that xylazine $\mathrm{HCl}$ administration can lead to oro-nasal discharge and urination $(6,9,14,20)$. In a study by Carvalho et al. (2), who intravenously administered $0.1 \mathrm{mg} / \mathrm{kg}$ xylazine $\mathrm{HCl}$, oro-nasal discharge was observed between the $15^{\text {th }}$ and the $90^{\text {th }}$ min, while urination was determined at the $60^{\text {th }}, 75^{\text {th }}$ and $90^{\text {th }} \mathrm{min}$. In our study, oro-nasal discharge began as early as 5 min after injection and continued at various intervals until the $75^{\text {th }}$ $\mathrm{min}$ at the latest. Urination was observed five times at most, between the $5^{\text {th }}$ and the $120^{\text {th }}$ min after injection.
The administration of $\alpha 2$-agonists may result in a decrease in body temperature, caused by the depression of the central nervous system (CNS) and reduced muscular activity (19). In more recent studies $(9,10,14)$, it was observed that rectal temperature decreases for a short period of time in sheep that have received xylazine $\mathrm{HCl}$. In our study, the rectal temperature increased by a maximum of $0.6^{\circ} \mathrm{C}$ above the control values in the first $90 \mathrm{~min}$ after the injection in all administrations.

Xylazine $\mathrm{HCl}$ administration provokes certain respiratory side effects as a result of the secondary depression of the CNS (23). The occurrence of xylazine $\mathrm{HCl}$-induced hypoxaemia varies significantly from one sheep breed to another, and from one individual animal to another. The extent of hypoxaemia does not depend on the specific $\alpha-2$ adrenergic receptor agonist used, but on the dose and resulting plasma concentration. Consequently, it is most serious following intravenous bolus injection (13). Several studies have shown that the respiratory rate decreased in animals after xylazine $\mathrm{HCl}$ administration $(4,9,14)$. In contrast, Ismaila et al. (10) reported an increase in the respiratory rate. Some authors have claimed that $\alpha-2$ agonists cause tachypnoea in sheep and bradypnoea in other ruminants. In addition, they also have stated that $\alpha-2$ receptor agonists have different effects on different sheep species and there 
Tab. 5. Findings of sedation

\begin{tabular}{|c|c|c|c|c|c|c|c|}
\hline Animals & $\begin{array}{l}\text { Starting time } \\
\text { of mild sedation } \\
\text { after xylazine } \\
\text { administration } \\
\text { (min) }\end{array}$ & $\begin{array}{l}\text { Duration of mild } \\
\text { sedation (min) }\end{array}$ & $\begin{array}{c}\text { Duration } \\
\text { of moderate } \\
\text { sedation (min) }\end{array}$ & $\begin{array}{l}\text { Duration of deep } \\
\text { sedation (min) }\end{array}$ & $\begin{array}{l}\text { Duration } \\
\text { of moderate } \\
\text { sedation during } \\
\text { recovery from } \\
\text { deep sedation } \\
\text { (min) }\end{array}$ & $\begin{array}{l}\text { Duration } \\
\text { of mild sedation } \\
\text { during recovery } \\
\text { from deep } \\
\text { and moderate } \\
\text { sedation (min) }\end{array}$ & $\begin{array}{l}\text { Total duration } \\
\text { of sedation } \\
\text { (min) }\end{array}$ \\
\hline & \multicolumn{7}{|c|}{$1^{\text {st }}$ application } \\
\hline The first animal & $5^{\text {th }}$ & 10 & 13 & * & * & 30 & 53 \\
\hline The second animal & $4^{\text {th }}$ & 11 & 41 & * & * & 16 & 68 \\
\hline The third animal & $6^{\text {th }}$ & 9 & 18 & 11 & * & 34 & 72 \\
\hline The fourth animal & $4^{\text {th }}$ & 6 & 11 & 24 & 35 & 15 & 91 \\
\hline \multirow[t]{2}{*}{ The fifth animal } & $5^{\text {th }}$ & 55 & * & * & * & * & 55 \\
\hline & \multicolumn{7}{|c|}{$2^{\text {nd }}$ application } \\
\hline The first animal & $6^{\text {th }}$ & 60 & * & * & * & * & 60 \\
\hline The second animal & $5^{\text {th }}$ & 10 & 20 & * & * & 35 & 65 \\
\hline The third animal & $4^{\text {th }}$ & 8 & 5 & 40 & * & 30 & 83 \\
\hline The fourth animal & $3^{\text {rd }}$ & 7 & 21 & 47 & * & 17 & 92 \\
\hline \multirow[t]{2}{*}{ The fifth animal } & $5^{\text {th }}$ & 50 & * & * & * & * & 50 \\
\hline & \multicolumn{7}{|c|}{$3^{\text {rd }}$ application } \\
\hline The first animal & $4^{\text {th }}$ & 65 & * & * & * & * & 65 \\
\hline The second animal & $5^{\text {th }}$ & 25 & 30 & * & * & 15 & 70 \\
\hline The third animal & $6^{\text {th }}$ & 22 & * & 30 & 12 & 22 & 86 \\
\hline The fourth animal & $3^{\text {rd }}$ & 5 & 5 & 25 & * & 38 & 73 \\
\hline \multirow[t]{2}{*}{ The fifth animal } & $7^{\text {th }}$ & 67 & * & * & * & * & 67 \\
\hline & \multicolumn{7}{|c|}{$4^{\text {th }}$ application } \\
\hline The first animal & $6^{\text {th }}$ & 52 & * & * & * & * & 52 \\
\hline The second animal & $4^{\text {th }}$ & 8 & 5 & 40 & * & 20 & 73 \\
\hline The third animal & $3^{\text {th }}$ & 7 & 73 & * & * & 15 & 95 \\
\hline The fourth animal & $4^{\text {th }}$ & 10 & 7 & 23 & * & 30 & 70 \\
\hline The fifth animal & $7^{\text {th }}$ & 62 & * & * & * & * & 62 \\
\hline
\end{tabular}

Explanation: * did not occur

are even individual differences within species (26). In our study, the respiration rate increased until the $15^{\text {th }}$ min, approached the control value at the $30^{\text {th }}$ min and decreased after the $45^{\text {th }} \mathrm{min}$.

Xylazine $\mathrm{HCl}$ reduces reticuloruminal activity and increases the chance of tympanism because it reduces eructation. It also decreases gastrointestinal motility by reducing acetylcholine release from the presynaptic terminals of post ganglionic parasympathetic fibres in the intestinal wall (5). Several previous studies $(9,10$, $17,20,25)$ have indicated that xylazine $\mathrm{HCl}$ decreases ruminal activity in sheep and causes tympanism. In the present study, rumen activity decreased until the $30^{\text {th }}$ min in all administrations, after which it increased until the $120^{\text {th }} \mathrm{min}$, but failed to reach the control values.

All $\alpha-2$ adrenergic receptor agonists are associated with cardiovascular effects, such as bradycardia and related arrhythmia, a drastic reduction in cardiac output, by up to $50 \%$, and enhanced systemic vascular resistance (23). Dose-dependent xylazine HCl-associated cardiovascular depression is less notable following intramuscular and extradural administration. A number of previous studies have reported a reduced pulse rate after $\alpha$-2 agonist administration $(2,4,9,10,14)$. It has been found that intramuscular $(0.05 \mathrm{mg} / \mathrm{kg})$ or intravenous $(0.02 \mathrm{mg} / \mathrm{kg})$ administration of xylazine $\mathrm{HCl}$ has no notable effect on the heart rate in sheep (7). Intravenous administration of $0.015 \mathrm{mg} / \mathrm{kg}$ xylazine $\mathrm{HCl}$ results in only a slight cardiovascular response (4). In our study, a decrease in the heart rate relative to the baseline was noted at every time point during every treatment, but it was not statistically significant.

Xylazine $\mathrm{HCl}$ administration results in dose-related sedation and nervous depression in sheep and goats (12). The duration of sedation and the level of analgesia are dose-dependent. Smaller doses produce moderate sedation of a shorter duration, while higher doses can produce deep sedation of a longer duration (19). Xylazine $\mathrm{HCl}$-induced sedation primarily results from stimulation of central a2 receptors (8). The degree of sedation is dose-dependent and correlates well with plasma drug concentrations (16). It was shown that rams that received an intramuscular administration of $0.3 \mathrm{mg} / \mathrm{kg}(24)$ or $0.2 \mathrm{mg} / \mathrm{kg}$ xylazine $\mathrm{HCl}$ (14) lay down 
15 min after injection. Recumbency was not observed in any animal after an intravenous administration of $0.1 \mathrm{mg} / \mathrm{kg}$ xylazine $\mathrm{HCl}$ (2). In our study, the sheep assumed a lying posture 8-30 min after the drug was first administered in all treatments. It was previously shown that sheep under sedation remained in a lying posture for $55 \mathrm{~min}$ (24), or for 90-105 min, according to Khan et al. (14). In our study, the sedation time for animals that were only mildly sedated varied between 50 and $67 \mathrm{~min}$, whereas sedation times for animals in moderate sedation varied between 13 and $73 \mathrm{~min}$. Sedation times for animals in deep sedation ranged from 11 to $47 \mathrm{~min}$.

$\alpha-2$ agonists produce profound analgesia, and can be administered parenterally and neuraxially (e.g., epidurally). Analgesia is produced by activation of $\alpha-2$ receptors in the CNS in the locus coeruleus and in the substantia gelatinosa of the dorsal horn of the spinal cord (19). Khan et al. (14) evaluated the xylazine $\mathrm{HCl}$ analgesia level in sheep with a score of between 4 and 6 . Grant and Upton (7), however, claim that a complete analgesic effect does not occur in sheep when xylazine $\mathrm{HCl}$ is administered intramuscularly. The analgesic effect of xylazine $\mathrm{HCl}$ differs among sheep species (15). In the present study, the degree of analgesia was determined as a score of only 1-2 during deep sedation. We believe that xylazine $\mathrm{HCl}$ has a mild analgesic effect on sheep during deep sedation.

Hyperglycaemia that has been reported in horses, cattle, sheep and dogs after the use of xylazine $\mathrm{HCl}$ is due to a decrease in insulin release from $\beta$ cells and/or an increase in glucagon release from $\alpha$ cells $(8,16,19)$. In previous studies, administration of xylazine $\mathrm{HCl}$ to sheep led to an increase in serum glucose concentration $(1,22)$. The results of the present study support previous findings in that xylazine $\mathrm{HCl}$ continued to produce a hyperglycaemic effect for a period of at least $120 \mathrm{~min}$ following its administration. It has previously been reported that xylazine $\mathrm{HCl}$ does not statistically alter serum $\mathrm{Na}^{+}, \mathrm{K}^{+}, \mathrm{Ca}^{2+}$ and $\mathrm{Cl}$ levels in sheep (2). In our study, there were no statistically significant differences in the values of some of the parameters (total bilirubin, BUN, AST, ALT, ALP, $\mathrm{Ca}^{2+}, \mathrm{Na}^{+}, \mathrm{K}^{+}$and $\mathrm{Cl}$ ).

In the present study, even though xylazine $\mathrm{HCl}$ administration resulted in only minor cardiovascular and rectal temperature changes, it decreased the respiratory rate (at all time points) and rumen motility (during the first 45-60 min after administration) in all treatments. It has a hyperglycaemic and weak anaesthetic effect in sheep. Repeated doses of xylazine $\mathrm{HCl}$ over several days are accompanied by the development of tolerance to the drug. This could be due to receptor downregulation/desensitisation or to the induction of hepatic microsomal enzymes for its metabolism (5). In the present study, four administrations were made at 4-day intervals. In all administrations in which the dose was increased by $20 \%$ relative to the previous administration, the same degree of sedation was obtained in four out of five sheep. Accordingly, it was concluded that in order to obtain the same sedation level in sheep in the 4 days following an administration of xylazine, the previous dose should be increased by $20 \%$.

\section{References}

1. Brikas P., Tsiamitas C., Ayiannidis A.: Xylazine-induced hyperglycaemia and a-adrenergic receptors in sheep. J. Vet. Med. A 1987, 34, 58-60.

2. Carvalho L. L., Nishimura L. T., Borges L. P., Cerejo S. A., Villela I. O. Auckburally A., de Mattos-Junior E.: Sedative and cardiopulmonary effects of xylazine alone or in combination with methadone, morphine or tramadol in sheep. Vet. Anaesth. Analg. 2016, 43, 179-188

3. Celly C. S., Mc Donell W. N., Young S. S., Black W. D.: The comparative hypoxaemic effect of four alpha-2 adrenoceptor agonists (xylazine, romifidine, detomidine and medetomidine) in sheep. J. Vet. Pharmacol. Ther. 1997, 20, 464-471.

4. Doherty T. J., Pascoe P. J., Mc Donell W. N., Monteith G.: Cardiopulmonary effects of xylazine and yohimbine in laterally recumbent sheep. Can. J. Vet. Res. 1986, 50, 517-521.

5. Dugdale A.: Veterinary Anaesthesia Principles to Practice. Wiley-Blackwell, 2010 , p. 281

6. Galatos A. D.: Anesthesia and analgesia in sheep and goats. Vet. Clin. North. Am. Food. Anim. Pract. 2011, 27, 47-59.

7. Grant C., Upton R. N.: Comparison of the analgesic effects of xylazine in sheep via three different administration routes. Aust. Vet. J. 2004, 82, 304-307.

8. Greene S. A., Thurmon J. C.: Xylazine-a review of its pharmacology and use in veterinary medicine. J. Vet. Pharmacol. Ther. 1988, 11, 295-313.

9. Habib S., Das B. C., Islam M. N., Hossain M. K., Ahmed M. F.: A Comparison of xylazine, diazepam, chlorpromazine and promethazine in relation to certain clinical and hematological parameters of indigenous sheep (Ovis aries). Pak. J. Biol. Sci. 2002, 5, 484-488.

10. Ismaila M. S., Onifade K. I., Agaie B. M., Elsa A. T., Chafe U. M.: The influence of environmental temperature on physiological parameters in xylazine sedated sheep. Int. J. Anim. Vet. Adv. 2010, 2, 37-42.

11. Karasu A., Genccelep M.: The effect of xylazine $\mathrm{HCl}$ used in repeated sedations for sheep on biochemical and clinical values. Kafkas Univ. Vet. Fak. Derg. 2015, 21, 831-836.

12. Kästner S. B. R.: A2-agonists in sheep: a review. Vet. Anaesth. Analg. 2006, 33, 79-96.

13. Kästner S. B. R., Wapf P., Feige K., Demuth D., Bettschart-Wolfensberger R., Akens M. K., Huntinen M.: Pharmacokinetics and sedative effects of intramuscular medetomidine in domestic sheep. J. Vet. Pharmacol. Ther. 2003, 26, 271-276.

14. Khan M. A., Ashraf M., Pervez K., Rashid H. B., Mahmood A. K., Chaudhry M. Comparative effects of detomidine and xylazine as sedative and analgesic agents in small ruminants. Pak. Vet. J. 2004, 24, 62-69.

15. Ley S., Waterman A., Livingston A.: The influence of chronic pain on the analgesic effects of the alpha 2-adrenoceptor agonist, xylazine, in sheep. J. Vet. Pharmacol. Ther. 1991, 14, 141-144.

16. Lizarraga I., Chambers J. P.: Use of analgesic drugs for pain management in sheep. N. Z. Vet. J. 2012, 60, 87-94.

17. Mohammad F. K., Wahed R. A., Dabbagh B. K.: Stimulation of food intake by xylazine in sheep. Zentralbl Veterinarmed. A 1996, 43, 387-391.

18. Nesgash A., Yaregal B., Kindu T., Hailu E.: Evalution of general anesthesia using xylazine-ketamine combination with and without diazipam for ovariohysterectomy in bitches. Vet. Sci. Technol. 2016, 7, 1-6.

19. Posner L. P., Burns P.: Sedative agents: tranquilizers alpha-2 agonists and related agents, [in]: Riviere J. E., Papich M. G. (ed.). Veterinary Pharmacology and Therapeutics. Wiley-Blackwell, Ames, Iowa 2009, p. 337-380.

20. Powell J. D., Denhart J. W., Lloyd W. E.: Effectiveness of tolazoline in reversing xylazine-induced sedation in calves. J. Am. Vet. Med. Assoc. 1998, 212, 90-92.

21. Rankin D. C.: Sedatives and tranquilizers, [in:] Grimm K. A., Lamont L. A., Tranquilli W. J., Greene S. A., Robertson S. A. (eds): Veterinary Anesthesia and Analgesia. Wiley Blackwell, Ames 2015, p. 196-206.

22. Raptopoulos $D .:$ The role of hypoxia in the hyperglycaemic effect of xylazine in sheep. J. Vet. Med. A 1990, 37, 215-219.

23. Shah Z., Ding M. X., Hu M. L.: A review on the current use of alpha2 agonists in small ruminants. Kafkas Univ. Vet. Fak. Derg. 2014, 20, 633-639.

24. Shokry M., Morad H. M., Khalil I. A.: Studies on the effect of rompun in sheep Vet. Med. Rev. 1976, 2, 237-243.

25. Toutain P. L., Zingoni M. R., Ruckbush Y.: Assessment of alpha-2 adrenergic antagonists on the central nervous system using reticular contraction in sheep as a model. J. Pharmacol. Exp. Ther. 1982, 223, 215-218.

26. Valverde A., Doherty T. J.: Anesthesia and analgesia of ruminants, [in:] Fish R. E., Brown M. J., Danneman P. J., Karas A. Z. (eds): Anesthesia and Analgesia in Laboratory Animals. Academic Press, London, UK 2008, p. 285-411.

Corresponding author: Prof. Dr. Musa Genccelep, Faculty of Veterinary Medicine, University of Yuzuncu Yil, Campus, 65080 Van/Turkey; e-mail: musacelep@yahoo.com 